\title{
The Art of War: Instability, Insecurity, and Ideological Imagery in Northern Ireland's Political Murals, 1979-1998
}

\author{
Gregory J. Goalwin \\ Department of Sociology, \\ University of California, Santa Barbara \\ Santa Barbara, CA, U.S.A.
}

\begin{abstract}
$\underline{\text { Abstract: }}$
This article examines the purpose behind, and rhetorical content of, political wall murals produced during the Troubles in Northern Ireland. I utilize a semiotic approach to analyze the ways that the symbolic content and physical placement of Northern Irish murals were used by actors on both sides of the conflict. I examine the major thematic traditions utilized by muralists on each side and situate them within the historical and political contexts of the conflict in Northern Ireland. This approach highlights the ways that murals did more than simply champion ideological causes, as earlier scholarship has argued, but served an active role in efforts to catalyze cultural support for organizations' political goals. I argue that murals played a key role for organizations on both sides of the conflict, as they each struggled to craft a communal selfidentification and legitimizing central narrative that furthered their ideological goals.

Organizations on both sides used murals to mobilize cultural support for their political and military struggles. In this regard, murals functioned as a form of mythic speech, attempting to depoliticize highly political ideologies and make the rhetoric used by the competing groups seem natural and pure. The grassroots nature of the mural traditions is particularly telling in this regard, exposing the deep-seated insecurity of organizations on both sides. This insecurity is further reflected by, and served as a catalyst for, the paramilitary violence that was a defining characteristic of Northern Ireland for so long.
\end{abstract}

Keywords: Northern Ireland; Nationalism; Political Propaganda; Cultural Politics; Murals

Published As:

Gregory Goalwin, "The Art of War: Instability, Insecurity, and Ideological Imagery in Northern Ireland's Political Murals, 1979-1998," International Journal of Politics, Culture, and Society 26, no. 3 (2013).

http://link.springer.com/article/10.1007/s10767-013-9142-y 
Northern Ireland's political wall murals, most adorning the walls of contested urban areas in Belfast and Derry, were a striking medium used by political activists on both sides of the Troubles to express their ideological messages and further their political goals. Despite their commanding visual presence and the significant volume of research dedicated to explaining the Troubles, few scholars have analyzed the deeper significance of the region's murals or analyzed the part they played in the larger conflict (Vannais, 2001). Much of the literature on the murals, led by scholars such Bill Rolston, Neil Jarman, and Jeffrey Sluka, has focused on the murals' role in expressing social themes and political debates prevalent during the conflict . Rolston (1987, 1991, 1992, 1995) and Jarman (1992) have emphasized the murals' role in the political culture of Northern Ireland, while Sluka $(1992,1996)$ argues that they are a means of expressing identity political and ethnic-national identity. This study seeks to build on the work of these scholars, examining the role that the production of Northern Ireland's political murals played in not only expressing political and ethno-national beliefs, but in actually constructing and expressing the communal identities and ideological messages of organizations on both sides of the conflict.

Northern Ireland has long been a deeply conflicted region. Significant social divides and the enduring legacy of centuries old religious wars have resulted in the creation, reinforcement, and institutionalization of two distinct and competing cultural traditions. The antagonism between these two traditions, often referred to as "Catholics" and "Protestants" in an oversimplification that more accurately reflects social organization during the seventeenth century than it does that of today, has led to repeated clashes. Despite the originally religious character of these traditions, with Protestant settlers from Scotland and Britain colonizing and dominating the Irish Catholics inhabitants, the modern expression of the conflict has been largely political and economic; it has, since the partition of Ireland in 1921, centered on the question of 


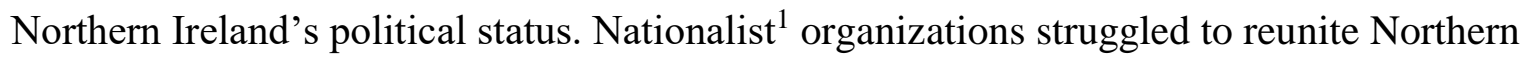
Ireland with the Republic of Ireland to the south and unionist organizations sought to maintain the region's position as part of the United Kingdom. These clashes culminated in the Troubles, a large scale armed conflict that officially lasted from 1968 to 1998 but which continues to produce sporadic instances of sectarian violence to this day.

This struggle between competing political ideologies caused a tremendous amount of instability in the region politically, as the legitimacy of the government was called into question. The conflict resulted in the proliferation of paramilitary organizations such as the Provisional Irish Republican Army (PIRA), Irish National Liberation Army (ILNA), the Ulster Volunteer Force (UVF), and the Ulster Defence Association (UDA), often acting politically as well as militarily. These organizations claimed to represent and protect the interests of the two cultural communities from which they drew their members, and sought to provide the security and safety that both communities felt the government was unable to supply. The political instability in the region was matched, however, by cultural instability within the two communities themselves as both sides struggled to construct and define their own collective identities and ideological aims. The creation of political wall murals, a practice which reached its peak between 1981 and 1998, was a highly visible part of this effort. Struggling with a crisis of legitimacy in the face of competing ideological narratives and their own often controversial paramilitary tactics, organizations on both sides of the conflict turned to murals in an effort to construct a narrative

\footnotetext{
${ }^{1}$ The terminology used to describe the two sides in the Northern Ireland conflict is often confusing and terms are often used without precision or clarity. This paper follows others in using "Nationalist" and "Unionist" to describe the overarching, and often peaceful, political movements of the two sides. "Republican" and "Loyalist" are used respectively to describe the radical paramilitarized and violent elements within these two political ideologies. The religious terms "Catholic" and "Protestant" although often used as stand-ins for these more political terms, are here used only when referring to religion.
} 
that would legitimize their ideological claims and help catalyze popular support for their political causes. In this regard, vibrant and conspicuous murals served as a means by which radical republican and loyalist organizations could gain support amongst the more neutral nationalist and unionist communities respectively. The decision to create political murals and the symbolic content chosen by republican and loyalist muralists reveal not only the political instability that is so evident in the armed conflict, but also a deeper tension within the competing communities themselves, as radical organizations on both sides of the conflict attempted to mobilize communities defined in cultural terms to accomplish what were explicitly political aims. The narratives constructed and expressed through the republican and loyalist mural traditions in Northern Ireland accomplished this goal, explicitly linking the cultural and the political and furthering the ideological purposes of organizations on both sides by explicitly challenging or reproducing the contested political order of the day. This paper will proceed by presenting a theoretical framework within which the conflict in Northern Ireland can be profitably analyzed, before turning to a brief discussion of methodology. A discussion of the historical context within which the Northern Irish mural traditions formed will then be followed by an analysis of the ways that the thematic content of the two mural traditions helped spur and support group formation, before a concluding section examines what such expressions of political and cultural identity mean for Northern Irish society.

\section{Theories of Group-making}

Scholars have long struggled to classify the modern conflict in Northern Ireland. The contested issues, discussed at length below, are fundamentally political, but the competing sides have most often been identified and defined using cultural, rather than political, criteria. This seeming disconnect has led scholars to advance a variety of theoretical explanations for the 
conflict, which has alternately been described as a political, religious, ethnic, Marxist class, or even "tribal" struggle (McGarry and O'Leary 2000). Ultimately, the debate about the conflict has focused on the nature of the two competing groups in Northern Ireland, with scholars defining the two sides using whichever criteria best fit their own theoretical perspective. Despite its ubiquity, this emphasis on groups and the impetus to neatly classify the struggle can cause significant problems for the study of Northern Ireland's political and cultural conflict. In his work on social space and symbolic power, Pierre Bourdieu has illustrated many of the problems inherent in treating such groups as real and tangible entities (1989). Bourdieu explains that academic and folk sociologies alike tend to take groups as a given, seeing them as unitary social actors with defined goals and rational plans of action. In his analysis of class distinctions Bourdieu argues that these groups are, in fact, socially constructed and internally diverse, defined and maintained through a dialectical relationship between subjective self-representation and objective social structural forms. Rogers Brubaker has built on this work and applied it to the study of ethnic groups and ethnic conflict. According to Brubaker, studies of ethnic conflict almost automatically take vaguely defined ethnic groups and refer to them as reified entities engaged in active struggle. Brubaker strives to move the scholarly analysis of ethnicity past this reification, and argues that group-making is actually a social, cultural, and political project, for him "ethnicity, race, and nation are ways of perceiving, interpreting, and representing the social world. They are not things in the world they are perspectives on the world" (Brubaker, 2004, p. 17). Brubaker argues that the protagonists of ethnic conflict and violence are not groups as such, but various kinds of organizations. Though these organizations draw their support from, and often claim to speak in the name of, larger ethnic communities, they are not coterminous with 
them, and the relationship between such organizations and their respective ethnic groups is often deeply ambiguous.

Brubaker's analysis of organizations involved in ethnic and political conflict can be fruitfully applied to the study of Northern Ireland, where a wide variety of paramilitary and political organizations actively involved in the conflict claimed to represent and speak for larger cultural groups, communities which were less politically oriented and far more diverse and unfocused. This tension between organizations and groups forced protagonists on both sides of the conflict to engage in the type of group-making Brubaker describes. Organizations on both sides engaged in significant propaganda efforts, designed to transmit the organizations' messages and ideologies to the populace in ways that would spur group formation and mobilize popular support for the organizations' political goals. In practice, the more radical elements of both political movements, republicans and loyalists, sought to rally the larger, and more neutral, nationalist and unionist communities to their respective causes. The war in Northern Ireland, although deadly, was thus fought as much through rhetoric and propaganda as through physical violence in what has been called a "war of words and symbols"(Sluka, 1996).

Art has long been a powerful tool by which social movements express their goals and ideologies. Many social movements have drawn upon a variety of artistic media; among many others the United States civil rights movement emphasized music, the women's movement utilized poetry, and organizations such as the Black Panthers employed theatrical drama in their movement politics (Reed, 2005). Murals themselves were utilized extensively by the Chicano movement in the United States, and have also appeared urging political change and liberalism in post-Apartheid South Africa. (Marschall, 2007). Most importantly, such utilizations of art linked political mobilization with cultural issues. Artwork allows social movement activists to construct 
an image of the world as they see it, litterally in the case of large visual media such as murals, creating a narrative that can help define the movement itself. Such efforts, with their explicit emphasis on culture, reveal the importance of culture and cultural politics in social movement mobilization. This is particularly true in the case of Northern Ireland, where the political struggle includes two such deeply entrenched cultural communities, ones connected to, but not necessarily coterminous with the political organizations involved in social movement activism on each side. Artistic imagery provided and disseminated powerful cultural symbols around which movements mobilized and which social movement organizations could use to form larger cultural groups in support of their cause.

The symbolic content of the murals thus played a crucial role in perpetuating and strengthening the divisions in Northern Irish society; it crafted opposing narratives using cultural and national myths that told the history of Northern Ireland in a way that supported their sides' own ideologies. Roland Barthes discussed the formation of such myths, and the role visual imagery can play in them, in his work on myth today. Drawing on the semiotic linguistic work of Ferdinand de Saussure, Barthes describes myth as a form of speech, a secondary semiotic system that incorporates linguistic signs to convey a new meaning (1972, p. 109). Barthes explains that focusing upon the mythical signifier as a single whole, including both meaning and form, is a dynamic process, creating and consuming the myth such that "the reader lives the myth as a story at once true and unreal" (Ibid, p. 128). This is a crucial process and reveals the very principle of the myth in that it transforms history into nature, "what causes mythical speech to be uttered is perfectly explicit, but it is immediately frozen into something natural; it is not read as a motive, but as a reason" (Ibid). In this sense, Barthes argues, myth serves as a form of depoliticized speech "giving historical intention a natural justification, and making contingency appear 
eternal" (Ibid, p. 142). In this, "myth has turned reality inside out, it has emptied it of history and has filled it with nature... Myth does not deny things, on the contrary, its function is to talk about them: simply, it purifies them, it makes them innocent, it gives them a natural and eternal justification, it gives them a clarity which is not that of an explanation but that of a statement of fact (Ibid, p. 143).

The images that muralists from both sides chose to incorporate into their work served as semiotic signifiers and reflected the creators' efforts to construct a national myth that made their version of Northern Ireland's history natural, pure, and innocent. These national myths helped feed and shape the two ideologies, creating grand narratives that organizations on both sides could utilize to solidify group identity and mobilize group support for political efforts. In this ideological struggle, each side of the conflict struggled to create a cohesive group in a process that Eric Hobsbawm has called the "invention of tradition." Hobsbawm argues that invented traditions establish and symbolize social cohesion, create legitimizing institutions, and inculcate beliefs and value systems which automatically imply continuity with the past. (Hobsbawm \& Ranger, 1983, p. 1) While Hobsbawm problematically distinguishes between invented traditions and what he calls "genuine" traditions, other scholars have noted that all traditions are in some ways invented, as groups struggle to maintain unity and social cohesion (van Henten \& Houtepen, 2001).

The process of identity and belief formation that Hobsbawm describes here as being the goal of invented traditions is of crucial importance to the construction of groups in divided and unstable societies such as Northern Ireland. Though the origins of Northern Ireland's two competing traditions are centuries old, organizations on both sides of the struggle constantly engaged in similar processes, continually reinventing both traditions in an effort to inculcate and 
promote their beliefs and value systems, protecting and furthering their political and ideological goals. Northern Ireland's tortured history resulted in valid arguments for groups on both sides of the political conflict. Republicans and loyalists both struggled to craft a unified and cohesive identity for their movements, as well as to frame their movements, ideas, and actions, in an effort to appeal to audiences in Northern Ireland and abroad. Efforts to construct such coherent traditions were made critically important by the creation of the Northern Irish state and the ensuing struggle between the two sides for political control of the region.

Attempts to invent the two dueling traditions, nationalist and unionist, in Northern Ireland were conveyed through a variety of media including literature, language, and political action, (Cleary, 2002) but the creation of political murals was one of the most striking and effective means of political expression on both sides of the conflict. These murals, still a significant element of Northern Ireland's political geography, and the choice of their location, imagery, and messages, have become emblematic of Northern Ireland and of the Troubles themselves. Bourdieu's analysis of symbolic power can again serve as a useful framework here. Bourdieu argues that symbolic struggles over the perception of the social world can take two different forms. Objectively, actors can use symbolic power to "exhibit a group, its size, its strength, its cohesiveness, to make it exist visibly." Subjectively, actors can try to "transform categories of perception and appreciation of the social world, the cognitive and evaluative structures through which it is constructed" (Bourdieu, 1989, p. 19). Political murals in Northern Ireland acted in both of these ways and targeted two separate audiences at once, serving as both internal and external propaganda. Subjectively, murals were a crucial component of the invention of traditions on both sides as the symbolic messages they conveyed fulfilled a variety of the functions that Hobsbawm discussed. Murals expressed ideologies, represented communities, and 
served as a means of defining self-identity for both the mainstream political movements and their associated radical paramilitary organizations and sectarian groups. In this way, mural creation served as a crucial technique in the social, cultural, and political project of group making that Brubaker describes. Both mural traditions worked to establish social cohesion and legitimize controversial beliefs, policies, and institutions; they attempted to craft group identities and imbue them with a sense of tradition. Objectively, the murals also addressed an external audience, attempting to make visible both movements' strength and continued existence. Because of their visibility, dramatic physical presence, and symbolic messages, murals became a key factor in the propaganda war for both sides of the struggle. These murals were crucial weapons in the 'war of words and symbols' and their creation was an "act of war on the walls (Sluka, 1996, p. 387).

\section{Methods and Sources}

This paper analyzes Northern Irish murals as an expression of, and key factor in groupmaking and the invention of traditions in Northern Irish society. In creating political murals, both sides chose images which helped craft and reinforce their own versions of Northern Irish history. The murals of Northern Ireland represented the most visible and powerful use of visual imagery for political purposes during the Troubles. Located largely in Belfast and Derry, the epicenters of much of the conflict in Northern Ireland, the dramatic visibility and physical presence of murals made them a natural medium for organizations attempting to transmit their ideological message to as wide an audience as possible. Northern Ireland's two largest cities, Belfast and Londonderry are highly segregated, with distinct and separate unionist and nationalist communities. Murals were often placed on, and in effect served as, the borders between such segregated districts, serving to define the boundaries of contested space and "help[ing] to make explicit the fact of residential segregation" (Jarman, 1998). Their liminal position between these 
distinct communities allowed murals to speak to both audiences at once, functioning subjectively and objectively to exhort one ideology while opposing the other, creating a symbolic boundary that mirrored and reinforced the physical divides between the two communities in Northern Ireland.

Though a significant number of murals remain extant, and indeed have even been turned into popular tourist attractions, many have disappeared, and recent efforts have been made by the Northern Irish government to remove the remaining murals as anachronistic reminders of a conflict both sides now wish to move past (Rolston, 2010). To remedy this deficiency of evidence, this study relies upon several collections of photographs of the murals by Bill Rolston (1991, 1992, 1995, 2003), Oona Woods (1995), and Jean Guiffan (1998). The University of Ulster's Conflict Archive on the Internet and the library of the Claremont Colleges in California also possess significant digital collections of mural photographs (Crowley, McCormick). Relying on secondary collections of images in this way automatically raises concerns of selection bias and lacunae in the treatment of the mural corpus. While they are rarely explicit in their methodology, these collections, compiled by academics throughout Northern Ireland and beyond, reproduce a wide variety of Northern Ireland's murals and when taken together provide as comprehensive a picture of the two mural traditions as possible. Though problems remain, utilizing these disparate collections in concert helps minimize the potential biases of any one author or collection, providing a more stereoscopic rendering of the ways that political organizations utilized murals in Northern Ireland.

This study follows Bill Rolston's work in identifying several key themes prevalent in each mural tradition (1992). Rolston, a sociologist at the University of Ulster, Jordanstown is the acknowledged expert on political murals in Northern Ireland and his works represent one of the 
most important collections of, and commentary on, the Northern Ireland's murals. Rolston's substantial fieldwork and long familiarity with the murals has allowed him to craft a typology of their thematic content, identifying the most prevalent themes among both republican and loyalist muralists during the conflict. This study follows Rolston's typology, laid out in his Drawing Support trilogy which follows the development of the twin mural traditions in Northern Ireland across the decades of the conflict ( $1992,1995,2003)$. It then proceeds to analyze these themes, examining the myths that each category of images signified and discussing how each of these functioned in the dual processes of group formation and the invention of tradition identified by Brubaker and Hobsbawm. Organizations on both sides of the conflict utilized visual imagery as a means of mobilizing support for their political struggle. An analysis of these symbolic images, and the ways that organizations on both sides used them, can reveal not only the ideological goals behind the two movements, but also the mechanisms by which organizations on both sides of the struggle sought to create a cohesive group, movement, and tradition, in order to harness enough support to achieve those goals.

Analysis of these images reveals that, although the loyalist and republican mural traditions utilized different symbols and focused on different themes, muralists on both sides carefully selected images and symbols which could advance their ideological goals and solidify group support for their cause. The loyalist mural tradition relied upon relatively few symbols and placed a heavy emphasis on the unionist history in Northern Ireland and its traditional connections with the United Kingdom. These murals evoked images of a glorious and dominant unionist past, and were meant to convey the historical legitimacy of the unionist presence in Northern Ireland, as well as its hegemony and control of society. In direct contrast, republican murals integrated a wide variety of symbols and themes, all of which were grounded firmly in 
the present, asserting that the republican movement and the PIRA and INLA are here now and here to stay. The symbolic themes on both sides of the conflict were chosen specifically to convey cultural myths that would reinforce their ideological arguments and serve as constitutive elements of the invented traditions that define both movements. A close analysis of the content of the two competing traditions reveals the ideological goals and strategies of both sides, as well as their greater implications for Northern Irish society.

\section{Historical Context}

Northern Ireland is a region` with a deeply divided cultural and political history. Long a contested region, the originally Catholic region that would become Northern Ireland was colonized by Protestant settlers from England and Scotland during the sixteenth and seventeenth centuries. These settlements were designed as an attempt to pacify and Anglicize the region, and the colonists were set up as a new ruling class by the English crown. This situation created a sharp dichotomy between upper class Protestants and the poorer and less powerful colonized Catholics. This economic and political stratification that nevertheless had its roots in religious difference persisted for centuries, and only intensified after the partition of Ireland in 1921. A wealthy but relatively tenuous Protestant/unionist majority held power from the partition of the island until the implementation of a power-sharing agreement in 1998. Faced with a strong Catholic/nationalist minority and the looming presence of the heavily Catholicized Republic of Ireland to the south, unionist leaders, in almost complete control of the state, took several repressive steps to ensure a continued unionist majority. The unionist government enacted policies of electoral, housing, and job discrimination, along with gerrymandering political districts, to disenfranchise nationalist voters and consolidate the insecure unionist majority (Darby, 1976). In the late 1960s, nationalist groups launched a civil rights movement based on 
principles used by the African American civil rights movements in the United States. Though initially nonviolent, this movement saw escalating violence on both sides and, following the climactic events of Bloody Sunday in January of 1972, soon evolved into the Troubles, an ethnopolitical conflict that shook the region until 1998 and whose echoes continue manifest themselves in sporadic violent incidents to this day. With the increase in violence, British troops were sent into Northern Ireland, ostensibly to protect the Catholic population from Protestant reprisals for the civil rights movement, and the British government soon took direct control of governmental processes. This direct action by the British state had a powerful effect on the conflict and upon Northern Irish culture.

The imposition of British control and the decision to send British troops into Northern Ireland had profound repercussions. While British troops were originally sent to protect the Catholic community and the civil rights campaigners from violent responses by loyalist mobs, the relationship between Catholics and the British Army soon became contentious and the troops began to support the Protestant cause, helping to prop up the status quo and unionist control (Thornton, 2007). Nationalists, many of whom already viewed the unionist community as the descendants of illegitimate settlers and an expression of British dominance, saw British troops on Irish soil as just another example of British imperialism. British troops soon came to be seen, in the eyes of the nationalist community, as a physical manifestation of the political and cultural repression that the civil rights movement had been designed to combat. The republican movement within the nationalist community soon began targeting British troops and army bases along with unionist targets. The Northern Irish police force, known as the Royal Ulster Constabulary (RUC), was drawn largely from the Protestant unionist population and they and the British Army often colluded with loyalist paramilitary organizations (Murray, 1998). This 
demographic trend, when combined with the loyalist paramilitary groups that proliferated in Northern Ireland, caused significant resentment in the nationalist community. Nationalists, largely confined to Catholic ghettoes and lacking the type of political power possessed by their unionist opponents, felt besieged on all sides and disenfranchised by an illegitimate government.

Throughout The Troubles the PIRA² pursued a military strategy known as "The Long War," a strategy designed to wear down British popular support for continued military action in Northern Ireland and drive out the British troops. The PIRA strategies included:

1. A war of attrition against enemy personnel which is aimed at causing as many casualties and deaths as possible so as to create a demand from their people at home for their withdrawal. 2. A bombing campaign aimed at making the enemy's financial interests in our country unprofitable while at the same time curbing long-term investment in our country. 3. To make the six Counties as at present and for the past several years ungovernable except by colonial military rule. 4. To sustain the war and gain support for its ends by National and International propaganda and publicity campaigns. 5 . By defending the war of liberation by punishing criminals, collaborators and informers (O'Brien, 1999, p. 23). (Emphasis added)

The PIRA had the weapons, skills, and technical training necessary to pursue these policies and the popular support they received from the nationalist community made the movement extraordinarily powerful. One of the most important aspects of the PIRA campaign was distributing propaganda, an effort that was considered essential to the movement, so essential that it was one of the primary responsibilities of Sinn Féin, widely considered to be the political arm of the PIRA (O'Brien, 1999, p. 128). Organizers in both the PIRA and Sinn Féin hoped that the combined effects of the PIRA campaign of violence and the propaganda war and political efforts launched by Sinn Féin would both rally Catholics to the republican cause and put pressure on the British military and politicians alike, forcing them to withdraw from Northern Ireland.

\footnotetext{
${ }^{2}$ Often known simply as the IRA and sometimes referred to as "the Provos."
} 
The British answer to the PIRA campaign was firm and, in the eyes of the nationalist community, unjust. As Bill Rolston has argued "repression has such a long and respectable history in Ireland that it is the first instrument which the state reaches for when faced with political problems" (Rolston, 1976). The British government, in direct control of Northern Ireland from 1973 onward, enacted several repressive measures under the aegis of the Special Powers Act and its successor the Northern Ireland (Emergency Provisions) Act. Operation Demetrius, a policy of internment without trial for anyone suspected of being associated with the PIRA, was launched in 1971 but was ineffective and spurred significant negative backlash against Britain. Those arrested were almost entirely Catholics, though few had any significant ties with the PIRA, and rather than crushing the movement, many scholars credit internment for a groundswell of popular support for the PIRA and a direct rise in PIRA violence (CAIN, b). On March 1, 1976 the British government, on the recommendation of the Gardner Commission tasked with studying terrorism in Northern Ireland, withdrew Special Category Status for Irish prisoners arrested under suspicion of membership in the PIRA, an act that had profound consequences (Gardiner, 1975). Special Category Status effectively guaranteed Irish prisoners "prisoner of war" status and certain rights. Chief among these was the right to not wear a prisoner's uniform. The removal of Special Category Status made Irish prisoners equal to other criminals, and delegitimized the nationalist community's struggle for independence.

Along with physical efforts to end the conflict in Northern Ireland through force and internment, the British government also took steps that were intended to win the propaganda war against the republican movement. Reframing interned republicans as criminals rather than prisoners of war was one such measure, but was hardly the only one. The British government viewed Sinn Féin as the mouthpiece for the PIRA and complicit in its "terrorist" activities. In an 
effort to quell the PIRA's guerrilla warfare and deny the movement support, the government often banned the British press from airing interviews with Sinn Féin politicians or PIRA volunteers. The British government put significant pressure on the $\mathrm{BBC}$ and other news organizations to support the official government view of the conflict, Sinn Féin, and other republican organizations, and deny any nationalist access to the media. Censorship began unofficially in 1971 in response to controversy over the internment policy and the actions of the British Army and culminated in an official ban in 1988 that prohibited British media from airing statements not only from the PIRA but also from legal political parties with elected representatives who held nationalist viewpoints (Moloney, 1991). British censorship aimed to choke off the 'oxygen of publicity' from the republican movement and diminish its appeal at home and abroad (Miller, 1994, p. 36). With the British government censoring the press and limiting the ways that Sinn Féin, the official party most closely associated to the movement, could communicate with the public in Northern Ireland and beyond, republicans turned to more localized and public ways of articulating their message.

\section{The Murals}

It was in this milieu that the twin Northern Irish mural traditions flourished. Mural painting was common to groups on both sides of the conflict but the loyalist and republican mural traditions have vastly different histories. The loyalist tradition of mural creation dates back all the way to 1908. Mural painting was a traditional part of the unionist celebration of The Twelfth, a commemoration of the Protestant victory over Catholicism at the Battle of the Boyne on the twelfth of July 1690 . The original loyalist mural artists were workers at the Belfast shipyards who used paint and other materials from their jobs to paint gable walls in honor of the Twelfth of July celebrations (Jarman, 1992). This celebration continues to be held today and, 
despite recent efforts to tone down the sectarian rhetoric, contains many elements offensive to the nationalist community, chief among them the loyalist tradition of marching parades, complete with echoingly loud traditional lambeg drums, through largely nationalist areas. ${ }^{3}$ The loyalist mural tradition was closely tied to the celebrations of the Twelfth of July and their thematic content, imagery, and physical location glorify Protestant unionist ideals, largely at the expense of the nationalist community. This connection with a traditional holiday made murals an important expression of unionist culture. This loyalist display was made even more powerful by the political dominance of the unionist cause as nationalist communities were often banned from holding their own parades, creating the same type of displays as unionists, and creating murals. The prevalence of loyalist murals and the decision by both the Parliament of Northern Ireland and the British government to allow loyalist images while corresponding republican symbols were banned, served to explicitly reinforce the political order and preserve the political and cultural dominance of the unionist community. Nevertheless, throughout most of their history loyalist murals were limited primarily to the Twelfth celebrations, similar parades on other holidays, and other cultural events. It was only with, and as a response to, the rapid growth of the republican mural tradition in the early 1980s that loyalist murals began to proliferate and move beyond their traditional role.

The republican murals in Northern Ireland presented a direct contrast to the loyalist mural tradition. The republican tradition of mural creation lacked the deep-seated cultural history of its loyalist counterpart for reasons due directly to the sectarian sentiments within Northern Irish society. Because of the job discrimination practiced by the unionist government, jobs in the

\footnotetext{
${ }^{3}$ In fact one mural argues, "There is no such thing as a nationalist area of Ulster only areas temporarily occupied by nationalists." (Rolston, 1998, p. 12)
} 
Belfast shipyards, considered very desirable, were reserved for Protestants. Barred from these jobs and less affluent in general, the nationalist community had no access to the raw materials necessary for mural creation and republican muralists unable to finance displays similar to those constructed by the loyalists. In addition to this economic disadvantage, many expressions of nationalist "Irish" identity were discouraged or banned outright by the unionist government. With its roots in the seventeenth century penal laws imposed on the entire island of Ireland by the British, discrimination against native Irish culture was deep-seated and only strengthened by the successor unionist government in Northern Ireland. "Thus with unionist culture dominant, nationalist culture was relegated to the margins of unionist society" (Rolston, 1991, p. 71) and expressions of cultural identity, such as republican answers to the loyalist parading tradition, were outlawed and dealt with harshly by the government. "Painting murals was not a civic duty for nationalists; more, it would have led to severe harassment by the armed police of the unionist state" (Rolston, 1992, p. iii). Not until the early 1980s did republican muralists find their voices and express their own version of artistic and spatial rhetoric.

The republican tradition of mural creation owes its beginnings to another example of political repression: the decision to impose internment on and, eventually, to withdraw Special Category Status from, prisoners suspected of membership in the PIRA. The withdrawal of Special Category Status was met with steadily escalating protests by interned members of the PIRA and the smaller Irish National Liberation Army which culminated in the deaths of ten hunger strikers in 1981. The strikes were led by Bobby Sands, PIRA volunteer ${ }^{4}$ and member of

\footnotetext{
${ }^{4}$ PIRA soldiers were known as volunteers, a reference to the organization's official Irish title Óglaigh na hÉireann (translated as volunteers, or warriors, of Ireland) established in 1913 before the Irish War of Independence and retained thereafter
} 
the British Parliament ${ }^{5}$ who, in 1979 during the blanket protests that preceded the hunger strikes, urged "that 'a massive Paint and Poster campaign' and a painting spree 'that would cover the countryside' should be started in order to put pressure on the British government and increase awareness and support for the prisoners" (Jarman, 1997, p. 234). This call for support led to an increase in political graffiti, the forerunners of full-blown murals, and set the stage for a tremendous surge of republican mural painting, a pointed show of resistance to British and unionist dominance.

Political murals served as an effective propaganda source for the republican movement and a means of expressing its ideology and continued efforts when faced with pressure from the British government and press corps, providing an underground, and yet still extraordinarily visible form of propaganda that could not be effectively censored by the British. ${ }^{6}$ Throughout its history the republican movement has utilized other cultural forms as a means of expressing their ideology, including music and literature, and has also made efforts to promote traditional Irish language and sport (Zimmermann 2002; Grant 1999). These efforts, though in some ways effective, lacked the visibility and accessibility of murals, which dominated the public sphere in Northern Ireland and were (and in some cases still are) visible to all, not just a limited audience of consumers. While the murals often were targeted at and specifically addressed the two competing communities in Northern Ireland, they also helped the republican message reach an international audience. While banned from airing interviews with republican figures, British and other international television reporters could, and often did, stand in front of the colorful and

\footnotetext{
${ }^{5}$ Sands was elected to Parliament as a member of Sinn Féin while on the hunger strike that resulted in his death. ${ }^{6}$ However there was significant effort to do just that. Many murals were vandalized with scrawled graffiti or paint bombs and there is some indication that there was an official British military policy ordering troops to destroy murals and other examples of republican propaganda.
} 
evocative political murals while giving their reports. These murals thus became emblematic of the Northern Irish conflict in the minds of many television viewers in the UK and abroad and simultaneously spread the republican ideology and message that the British government had tried to contain.

The historical power relations in Northern Irish society have thus had a crucial effect on the development of both mural traditions. Jeffrey Sluka has drawn on the work of Michael Taussig to identify what he calls a 'culture of terror' and a 'culture of resistance' in the divided and sectarian nature of Northern Irish society, as unionists and nationalists struggled for control of the war-torn region (Sluka, 1995). Loyalists, fighting to remain in control, deliberately used repressive and violent techniques in an effort to terrorize the nationalist minority and quell republican activity and resistance. In answer, the republican movement remained defiant, expressing its continued struggle and fostering a culture of unbroken and unintimidated resistance. The thematic content of the murals produced by both sides of the conflict evocatively represent these cultures, as organizations from each side struggled to advance their political goals and rally greater community support for their causes.

\section{Loyalist Murals}

Loyalist muralists took great pains to establish a connection between the modern Northern Irish unionist community and both the historically dominant unionist past and the United Kingdom itself. Loyalist murals were largely clustered in the Protestant East Belfast and Shankill regions of Belfast, and in the Fountain, Bond's Street, Lincoln Courts, and Irish Street areas in East Londonderry. Loyalist mural imagery tended to fall into three major categories: 1) depictions of historical events, 2) portrayals of armed and threatening paramilitary soldiers, and 3) depictions of symbolic expressions of identity such as flags, crests, and coats of arm. There is 
a significant historical progression in the use of these themes, while images of historical events were most common in the early loyalist murals, created during the 1970s and early 1980s, more explicitly threatening images of paramilitaries during the mid 1980s, and the crests of their organizations in the 1990s predominated as the conflict intensified. This progression was matched by a change in the identity of the muralists themselves. Little research has been done on the muralists themselves, a significant lacuna in the scholarly literature, but it appears that while early loyalist muralists tended to be lone artisans, decorating gable walls in Twelfth of July celebrations later muralists often received commissions directly from loyalist organizations to produce murals (Vannais, 2001). All three major themes reveal efforts by loyalist organizations to construct a unionist tradition and self identity that emphasized unionist strength, solidarity, and history. These organizations sought to legitimate the unionist presence and dominance in Northern Ireland and to build community support behind their political goals. The effort to establish continuity with a mythic and storied historical past and community with the United Kingdom reveals the deep-seated insecurities of the loyalist movement and what it felt was the tenuous nature of both loyalist organizations' role within the greater unionist community, and the role that the larger unionist community played in Northern Irish society. While unionism was powerful and deeply entrenched in Northern Irish society, loyalist organizations continued to fear abandonment by the United Kingdom, the victory of republicanism, and reunification with the Republic of Ireland. This insecurity is further reflected by the portrayals of loyalist paramilitaries, established on the local level, often by the paramilitaries themselves, rather than officially sanctioned by the government. Portrayals of loyalist paramilitaries poised to defend unionist interests and fight for the preservation of unionist control provide powerful images, but 
also reveal such organizations' unstable standing within the greater cultural community and represent efforts to mobilize popular support for their cause.

\section{Historical Events}

The earliest loyalist murals sought to provide legitimacy for the Protestant ascendancy and the political status quo by portraying significant events from the region's history. The single most popular image portrayed in loyalist murals was that of "King Billy," William III of England, whose victory in the Battle of the Boyne, though long predating the establishment of Northern Ireland as a political entity, represents a watershed in unionist history and has become the defining moment symbolizing and legitimizing Protestant ascendancy and cultural dominance. King Billy's prominence in the loyalist mural painting tradition is not surprising, given the cultural connection between loyalist mural painting and the Twelfth of July celebration. King Billy was almost always depicted attired in a spotless uniform astride a white horse as it crossed the River Boyne, a white knight come to break the siege of Londonderry and defeat the Catholic forces of King James. King Billy was a Protestant but was actually supported by the Catholic Pope in his struggle for the throne, a strange affiliation for the man held up as the greatest hero of Northern Irish Protestantism. This did not matter to loyalist muralists, however, who selectively portrayed history in a way that provided a justification for the supremacy of the unionist cause. The Battle of the Boyne played a central role in the unionist narrative, providing a historical foundation for Protestants' continued presence in what would become Northern Ireland and for the political system that kept them in power. This battle has entered into Protestant mythology, and King Billy's inclusion in the corpus of mural themes reflects the cultural and political hegemony enjoyed by unionists throughout much of Northern Ireland's history. King Billy, as a symbol of unionism's victory, is an expression of dominance and is an 
explicit message (as is the entire celebration of the Twelfth of July) to the unionist and nationalist communities alike. By focusing on King Billy, loyalist muralists simultaneously urged unionists to remember their triumphal history and reminded nationalists of their defeat and the centuries of oppression which they should have no hope of overturning.

In addition to King Billy, the second major historical event that appeared in loyalist murals was the 1916 Battle of the Somme during World War I (Rolston, 1992, p. 11). One of the bloodiest battles of the war, and indeed of history, the Somme achieved mythic status in the loyalist community. After the outbreak of WWI, volunteers from the Ulster Volunteer Force (originally a unionist militia and only in the 1960s reconstituted as the modern paramilitary organization that shares the same name) formed the $36^{\text {th }}$ (Ulster) Division and fought with the United Kingdom. Made up almost entirely of Protestant unionists, the Ulster Division saw significant action and distinguished itself during the Battle of the Somme. Despite suffering heavy losses, the Ulster division was one of very few to achieve its objective and make significant gains. This battle was of significant import to the unionist community. The Ulster Division's service during WWI served as a link between unionists and the United Kingdom, and the unionist community was proud of its willingness to support and defend the state. Murals memorializing the sacrifices made by the Ulster Division emphasized the unionists' commitment to the United Kingdom. Such commitment should be matched, the murals argued, by the United Kingdom's dedication to and support for the unionist cause. Continued remembrance and commemoration of the Ulster Division's sacrifice served as a pointed message, intended to remind the British government and its people of the responsibilities they had to support the unionist community that had supported them so vigorously in their hour of need. Murals depicting the Battle of the Somme thus addressed two separate audiences, subjectively exhorting 
current unionists to match the fervent loyalty and uphold the glorious tradition of their predecessors by supporting or joining paramilitary organizations, and objectively making the continued plight of unionist in Northern Ireland visible to audiences within the rest of the United Kingdom.

Murals emphasizing historical events such as the Battle of the Somme and King Billy's victory at the Battle of the Boyne served an important function for loyalist paramilitary organizations. Nationalist efforts to reunite Northern Ireland with the Republic of Ireland frequently emphasized the alien nature of the Protestant ascendancy, which stemmed from seventeenth century British efforts to colonize the region by importing a ruling class of English and Scottish Protestants, in an attempt to characterize the Protestant dominated political system as illegitimate and unfair. The portrayal of historical events which depict the Protestant ascendancy in a positive light worked to establish the legitimacy of the political system. By emphasizing unionism's long history in Northern Ireland, significantly predating its existence as a distinct political region, loyalist murals sought to create a powerful narrative, inventing a tradition which legitimized the status quo and the relations of authority in Northern Ireland in the way described by Hobsbawm. Both the Battle of the Somme and the Battle of the Boyne, two historically significant battles in which British and Protestant Northern Irish fought and worked together, further represented an important connection between unionists and the United Kingdom. By establishing this connection, loyalist muralists strove to strengthen ties between Northern Ireland and the United Kingdom, establishing the unionist cause as a British one as well. In this way, Northern Irish loyalists sought to create a group, crafting an artificial community that conflated British and unionist identities in an effort to gain British support for 
the cause and establish a legitimate basis for an insecure Protestant dominance faced with significant challenges from the nationalist movement.

\section{Loyalist Paramilitaries and the Armed Conflict}

The second, and most overtly violent, category of images present in loyalist murals showed pictures, images, or silhouettes of armed loyalist paramilitaries in either watchful poses or firing weapons at an unseen republican enemy. Murals emphasizing the paramilitary soldiers themselves were predominant during the mid to late 1980s, reflecting loyalist anger over lack of support from the British government and the success of republican propaganda and paramilitary efforts. (Rolston, 1992) These portrayals emphasized the loyalist movement's dedication to the armed struggle, matching republican guerrilla tactics with violence of their own. These murals were explicitly threatening, often including textual messages such as, "The UVF reserve the right to strike at republican targets where and when the opportunity arises" (Rolston, 1992, p. 19). In a society that has seen so much violence, these murals sent a powerful message to unionists and nationalists alike. Faced with the violence perpetrated by republican paramilitaries, unionists could be reassured by depictions of soldiers willing and ready to defend them from harm. Images of soldiers defending unionist territory drew a connection between the paramilitary organizations and the communities they claimed to represent. The murals thus served an internal purpose. They exhorted the unionist community to remain firm in the face of adversity, rallied support for the military struggle against republican efforts, and encouraged support for the organizations themselves. At the same time, and just as important, images of armed soldiers sent a message warning republican paramilitary organizations that they would not triumph. Explicitly designed to be threatening and violent, paramilitary murals represented the loyalist community's willingness to do battle for their position in Northern Irish society and their belief in both the 
legitimacy of their cause and the illegitimacy of republican efforts to end unionist control of the region. These messages, strategically placed in Northern Ireland's urban geography and portraying looming images of paramilitary volunteers actively engaging in acts of violence, were extremely powerful. They emphasized the role of violence in the conflict and maintained a show of symbolic force and willingness to kill, even when loyalist paramilitaries themselves were not present. They ultimately helped to convey and accentuate the atmosphere of terror that permeated Northern Ireland during the worst of the Troubles.

Images of paramilitary soldiers inscribed boundaries on the cultural and physical geographies of Northern Ireland in a very real and threatening way. Violent images of paramilitaries conveyed the message of harsh punishment for any who would transgress the boundaries between the segregated Protestant and Catholic communities. Such images offered protection to unionist communities while explicitly asserting loyalists' willingness to inflict violence on those, such as the adjoining nationalist communities and even dissident Protestants, who were outside of their cultural group. This imposition of boundaries, both physical and cultural, worked to solidify the identities of both groups by creating a sharply defined "self" and "other." By placing representations of their own soldiers at the center of this boundary defining process, paramilitary organizations could claim to represent the unionist cultural group, and the promise of protection encouraged the unionist community to support paramilitary organizations and their efforts on behalf of the unionist population.

\section{Flags, Crests, and Slogans}

The final thematic focus of the loyalist mural tradition was on flags, coats of arms, slogans, and other inanimate portrayals of loyalist ideology. Most prevalent during the 1990s, such murals emphasized inanimate expressions of identity without portraying the people 
themselves, "as if loyalist mural painters no longer knew where loyalist people fitted" (Rolston, 1995, p. ii). Prominent among these were the Union Flag, the Red Hand of Ulster, portrayals of the British crown, and the shields and slogans of the loyalist paramilitary organizations including the Ulster Defence Association (UDA), Ulster Freedom Fighters (UFF), Ulster Defence Force (UDF), and the Ulster Volunteer Force (UVF). The use of flags and images such as these were particularly powerful in the political context of Northern Ireland. The Flags and Emblems (Display) Act was passed by the Northern Ireland Parliament in 1954 and provided that

1)Any person who prevents or threatens to interfere by force with the display of a Union flag (usually known as the Union Jack) by another person on or in any lands or premises lawfully occupied by that other person shall be guilty of an offence against this Act 2) Where any police officer, having regard to the time or place at which and the circumstances in which any emblem is being displayed, apprehends that the display of such emblem may occasion a breach of the peace, he may require the person displaying or responsible for the display of such emblem to discontinue such display or cause it to be discontinued (Flags and Emblems (Display) Act (Northern Ireland) 1954).

The act goes on to authorize the police to enter private property without a warrant and seize these provocative emblems when necessary. Although not specifically mentioned in the act, display of the Irish Tricolour, official flag of the Republic of Ireland, was especially targeted. ${ }^{7}$ Many nationalists saw the act as another effort to oppress nationalist culture. In Northern Ireland both sides of the conflict claim continuity and kinship with a neighboring state. Unionists have struggled to maintain connections with the United Kingdom while nationalists have sought to unite Northern Ireland with the Republic of Ireland. Because of these efforts, the national flags of the UK and the Republic of Ireland have taken on increased importance as symbolic

\footnotetext{
${ }^{7}$ Most notably lan Paisley, leader of the Democratic Unionist Party, demanded that police remove an Irish Tricolour from the head office of Sinn Féin, a confrontation which led to rioting and confrontations between republicans and police forces. Paisley protested that the display was provocative and was a deliberate insult to the unionist community. In practice, however, the demand came in the midst of a highly contested election campaign for the British House of Commons, and the confrontation over the flag galvanized unionist supporters and secured electoral victory.
} 
representations of each cause and claims of legitimacy. That the act specifically allowed, and defended, the display of the Union Flag made it a powerful symbol of loyalist ideology and reemphasized the cultural and political dominance of the unionist cause. Unionists proudly displayed the flag in a variety of contexts, continually expressing their political power and conspicuously emphasizing the privileged position of the unionist culture.

The use of the Union Flag served another purpose for the unionist community, expressing, as did images of the Somme, solidarity with and dedication to the United Kingdom. This was essential for a deeply insecure community whose political survival regularly depended on the support of a disinterested and often times frustrated British Parliament. While the unionist community in Northern Ireland has remained firm in its desire to remain a part of the United Kingdom, the British government has been less so. The partition of the island in 1921 created a Northern Ireland that would incorporate as much land as possible while still keeping a Protestant majority. This redrawing of political boundaries resulted in a country with an slim Protestant majority, providing a small margin for unionists who sought to stay in control. The agreement that resulted in the separation of Northern Ireland from the rest of the island included a provision that allowed for a referendum in which the Northern Irish population could vote to leave the United Kingdom and unite with the Republic of Ireland. Were this to happen, the unionist community would have gone from a slight majority in Northern Ireland to an extreme minority in the Republic of Ireland. This possibility made the connection to the United Kingdom of paramount importance to the unionist community; representations of British identity and culture and claims to unity with the United Kingdom, became important symbolic expressions. The long war strategy of the PIRA and its effects made this even more important for the unionist cause. Frustrated by republican violence as well as the mounting financial costs and loss of lives that 
resulted from the continued British military and political presence in Northern Ireland, the British Parliament repeatedly considered withdrawing and either allowing Northern Ireland to unite with the Republic of Ireland or become its own independent state (FitzGerald, 2006). Efforts to claim a shared identity with the United Kingdom, most visibly expressed in the decision to portray the Union Flag and other British symbols in the symbolic content of loyalist murals, served as an important part of unionist strategy to remain a part of the United Kingdom.

The shields, emblems, and slogans of the loyalist paramilitary organizations, when depicted in conjunction with the Union Flag, symbolized the loyalists' willingness to fight for their 'Britishness' even if Britain itself was willing to turn its back on them. While the British Army was involved in fighting the paramilitary efforts of the PIRA and other republican organizations, loyalist paramilitary organizations proliferated as well. These organizations defended unionist neighborhoods and carried out violent attacks on nationalist areas, targeting opposing paramilitaries and civilians alike. Portrayal of paramilitary shields emblems and slogans emphasized the loyalists' commitment to armed struggle and willingness to both kill and die for their cause.

One of the symbols used extensively in loyalist paramilitary crests and elsewhere in loyalist murals was the Red Hand of Ulster. Originally a symbol used by both sides, the Red Hand had come to symbolize the loyalists' willingness to fight on, whatever the cost. This symbol, drawn from the seal of the O'Neill family, in one version of the story refers to a mythic boat race between two chieftains who desired to claim a particularly contested portion of land. The chieftain who touched land first, it had been decided, would gain control of it. Seeing that he would lose the race, the O'Neill purportedly cut off his own hand and hurled it ahead of the boat, thereby touching land first and winning both the contest and the disputed land. This willingness 
to prevail in the face of defeat, despite all odds, is attractive to both sides of the Northern Irish conflict, and the symbol has been heavily used by loyalist organizations. Portrayals of symbols such as this, incorporated within shields and emblems of organizations that utilized violent tactics to support their ideologies, was a powerful and threatening statement of intent and dedication. All together, these symbols helped reinforce the cultural hegemony of the loyalist cause and have helped to further both sectarianism and the culture of terror that were endemic in Northern Ireland during the Troubles.

Symbolic expressions of identity such as flags, crests, and coats of arms engaged in the process of group formation at both the subjective and objective levels as described by Bourdieu. Subjectively, flags and paramilitary crests sought to transform categories of perception through the reinterpretation of historical events that linked unionists in Northern Ireland with Britain itself. The incorporation of the Union Flag in a variety of loyalist paramilitary crests and its frequent appearance in a wide variety of loyalist murals deliberately sought to turn the unionist cause into a British one, striving to meld unionists and the British population into one cohesive group from which loyalist paramilitary organizations could draw support. Objectively, murals worked to make visible not only the paramilitary organizations whose crests they bore, but the larger socially constructed group as well. Loyalist murals sought to emphasize the strength and cohesiveness of the paramilitary organizations and their associated cultural group in an effort to speak internally to their own community, in a bid for support, and externally to their republican opponents, in a show of unified force. Despite their power, such murals betrayed the insecure position of loyalist paramilitary organizations and the unionist community itself. They revealed loyalists' efforts to mobilize British and unionist support alike in a continuous struggle to remain 
relevant within the unionist community and to retain political and social control in Northern Ireland.

When taken as a whole, the three main themes of the loyalist mural corpus reveal significant efforts by loyalist organizations to mobilize popular support for their political goals. Loyalist paramilitary organizations sought to craft and express a powerful collective narrative, an invented tradition that would legitimize and help perpetuate the relations of political and social authority in Northern Irish society. The visual images presented in such murals attempted, in the process Barthes elaborated, to construct a national myth that legitimized, purified, and made eternal, a deliberately engineered version of Northern Irish history. This mythos presented the Protestant dominated political system as natural, fair, and legitimate, evoked a close and intimate relationship between the unionist struggle and the United Kingdom, and portrayed loyalist paramilitaries as the heroic guardians of a fragile, but ultimately just, political system under constant threat from the dangerous and violent "terrorists" of the republican movement.

\section{Republican Murals}

Republican muralists also utilized powerful images and themes in an effort to construct a collective identity and cohesive movement that would be recognized as legitimate and supported by not only the government and people of Northern Ireland, but by the international community as well. Republican murals were located largely in the Catholic Falls Road, Ardoyne, and Upper Springfield areas of Belfast, and the Bogside, Foyle Road, and Creggan Areas of Londonderry. Compared to loyalist efforts, the republican mural tradition relied on a much more varied and diverse corpus of symbols and images in its efforts to express nationalist ideology. This variation was a reflection of the decentralized nature of republican mural painting, as political activists worked independently to respond to changing political circumstances (Vannais, 2001), but did so 
in a way that consistently sought to advance the goals of republican organizations. Whereas the loyalist tradition sought to preserve the status quo, the republican tradition was revolutionary and supported a movement that sought to overthrow the government and seek social change. In this regard, although republican political organizations strove to rally popular support for their political goals just as their loyalist counterparts did, they went about this process in a very different way. Republican organizations were illegal and lacked even the tacit acceptance by police and the British military that was enjoyed by loyalist organizations. This was a significant challenge and the republican tradition spent a great deal of effort attempting to legitimize the movement's goals and methods. Republican muralists sought to emphasize the human cost of the struggle and the nationalist community's mistreatment at the hands of the authorities and loyalist groups; in this way they justified the advent of republican organizations that claimed to be protecting the community and fighting for civil rights. Republican murals touched on historical events but, in contrast to loyalist tradition, focused much more on the present and the continuing struggle against loyalists and the British. Republican murals tended to fall into five main themes: 1) depictions of the hunger strikers and other martyrs to the republican cause 2) memorials to other, often innocent, victims who died in the conflict, 3) claims to continuity with other revolutionary and civil rights movements around the world, 4) symbolic expressions of identity such as flags, crests and coats of arms, and 5) representations of paramilitary soldiers and the armed struggle itself. Unlike the loyalist murals, there was very little progression over time in the themes chosen by republican muralists. All five primary themes were present in republican murals from the beginning, and although there was some drop off of paramilitary images in the 1990s, such murals continued to be produced even then. The themes that republican muralists chose reveal the ways that republican organizations sought to frame the movement's message 
and construct a legitimate and effective nationalist tradition that could lend support to the organizations' goal of achieving real political change.

\section{Bobby Sands, Hunger Strikers, and Republican Martyrs}

Given their genesis in the publicity campaign that accompanied the 1981 hunger strikes, it comes as no surprise that the fate of the prisoners in the Long Kesh H-blocks was a prominent motif in the first murals. Hunger striker and member of the British Parliament Bobby Sands served as the republican counterpart to King Billy as the single most common individual featured in mural portraits. Sands was a prolific writer and his quotations often appeared, either with or without an accompanying portrait, on murals. Poignant quotations such as, "Everyone, Republican or otherwise, has his or her own particular part to play, no part is too great or too small, no one is too old or too young to do something" and, "Our revenge will be the laughter of our children," were particularly popular (Rolston, 1992, pp. 27, 47). In addition to powerful and evocative quotes, Sands' writings provided the imagery for another popular theme. In a story called "The Lark and the Freedom Fighter" Sands compared his struggle to that of a lark, imprisoned in barbed wire, striving for freedom. Sands' lark appears in many republican murals as a symbol of the continued struggle for freedom and was used in later murals by Sinn Féin politicians campaigning for office (Rolston, 1992, p. 41). Sands, as both a martyr for the republican cause and a British MP, was a powerful symbol. Republicans saw in Sands the ultimate expression of their political rhetoric, a man who was willing to endure unspeakable pressure and pay the ultimate price for his beliefs.

Images of other, nonspecific, hunger strikers, often coupled with religious imagery, and representations of the $\mathrm{H}$ shaped buildings of the Long Kesh prison itself, also appeared in the earliest republican murals in an effort to humanize the struggle and show the power of the 
participants' beliefs. Hunger strikers in the murals, with their naked emaciated bodies and bearded visages, were portrayed as Christ-like martyrs to the cause, a religious connection that was often made explicit through accompanying depictions of rosaries, bibles, praying relatives, and protective guardian angels. It is striking to note that although the two sides in the conflict in Northern Ireland have come to be defined by religious identity, there were very few religious symbols present in political murals. The mural traditions from both ideologies focused almost exclusively on the political and cultural conflict between the two sides, with little depiction of spiritual matters. The H-blocks themselves were often depicted along with the hunger strikers who languished in them. Hunger strikers were commonly portrayed as rising up and breaking the $\mathrm{H}$ with their backs, symbolizing the enduring strength of the republican movement despite their suffering. Although the hunger strike ended with the death of ten prisoners in 1981, the suffering of the hunger strikers continued to be a popular theme for muralists who celebrated many important anniversaries of the hunger strikes by creating new murals memorializing those who died (Rolston, 1992, p. 33).

Indeed, the portrayal of Bobby Sands and the other hunger strikers who died drew upon a long cultural tradition of Irish martyrdom. The depictions of Sands and others who gave their lives for the movement were crucial to the mystique of the republican movement and the morale of the republican community. Faced with overwhelming odds and struggling to overthrow a powerfully entrenched political system, the republican movement suffered many setbacks. Emphasizing the strength inherent in martyrdom and the continued struggle in the face of crushing opposition allowed republican organizations to absorb losses and reframe them as a necessary step in the path towards revolution. The few historical events and figures that were routinely portrayed in republican murals: the heroic death of the mythical figure Cú Chulainn, 
the failed 1916 rebellion in Dublin known as the Easter Rising, and busts of two of the Easter Rising's leaders, James Connolly and Patrick Pearse, served to glorify those who died for the republican movement and create a mythic past populated by heroes who sacrificed everything for the cause of Irish freedom. Murals glorifying past heroes of the republican movement also helped establish the legitimacy of the current incarnation of the republican movement, led by the PIRA and Sinn Féin, and drew a thread of continuity between the early Irish revolutionaries and the contemporary armed struggle. In this the republican muralists constructed a revolutionary tradition, crafting a historical narrative that emphasized the current movement's position within a long history of Irish nationalism and resistance to British control. This type of propaganda, which connected heroes and martyrs from a variety of historical time periods to those fighting in the modern struggle, helped establish a sense of collective identity for current members of the movement and validated the sacrifices made by those still willing to fight for the cause. In Barthesian terms, allusion to a continued tradition of republican revolutionary efforts naturalized such sacrifice, making a modern and historically contingent movement appear eternal and unbreakable. For a movement that relied upon both the support of the populace and the continued belief in what, at times, seemed an impossible goal, this type of message was essential to cultivating the popular support that helped maintain the PIRA and other republican organizations.

Portrayals of Irish republican martyrs served a dual rhetorical purpose for the muralists who used them. Like loyalist portrayals of historical events, depictions of early martyrs helped create an invented narrative tradition that asserted Irish republicanism's old roots and legitimacy. Republicanism's strong emphasis on the modern martyrs of the hunger strikes revealed the importance of the republican tradition in the present. The portrayal of Sands and his compatriots 
(convicted for violent offenses as members of a "terrorist" organization) as suffering victims of an unjust political and legal system worked to reframe the conflict and transform categories of perception. Those who gave their lives in the republican cause, whether as hunger strikers or in combat, were not terrorists guilty of terrible crimes in this tradition, as British and loyalist propaganda would argue, but suffering martyrs whose cause was worthy of community and popular support.

\section{Memorial Murals}

Murals that memorialized Bobby Sands and the other martyrs were also part of a larger memorial trend in republican mural painting. Unlike loyalist murals, many republican murals focused explicitly on the human costs of the conflict. In a movement consumed by the desire to continue the fight no matter what the cost, and significantly invested in portraying an unbroken resistance, veneration of those who gave their lives to the cause was a crucial iconic device. Many murals throughout Belfast and Londonderry listed the names of the hunger strikers and important political leaders, but others provided lists of rank and file PIRA volunteers who died during armed actions against British troops and loyalist paramilitary organizations. Other murals portrayed the names and faces of people, often children, who died in plastic bullet attacks by British troops. Plastic bullets were intended to be used in crowd-control situations as a supposedly non-lethal alternative to traditional rounds (Rolston, 1992, p. 45). When used in nonriot situations, however, and when aimed at victims' heads, the rounds could be lethal. Because of these deaths, and the large proportion of children among the victims, the use of plastic bullets was particularly provocative and many murals responded with phrases such as, "They call the killing of Stephen McConomy Civil Order," and the pointed question, "Who Next?" appearing next to portraits of the slain (McKittrick, 1999). Depictions of the funeral of Bobby Sands, which 
was attended by over 100,000 mourners, were also popular, with the most common image being that of Sands' fellow PIRA volunteers firing a final salute over his coffin and grave. Memorials to the dead served an important purpose in republican propaganda. The invocation of the names of the dead functioned as both an exhortation to those still fighting and a remembrance of those who gave their lives so that the struggle might go on.

Memorials to the dead also served another, more strategic, purpose for the nationalist movement: garnering support. In addition to its efforts to reunite Northern Ireland and the Republic of Ireland, the current iteration of the nationalist movement in Northern Ireland arose as part of the civil rights movement seeking to end the mistreatment that the Catholic community suffered at the hands of the Protestant unionist majority. Following the decision to send British troops into Northern Ireland, the takeover of government control by the British, and the imposition of other policies such as internment without trial, republicans attempted to expose the repressive tactics utilized by the British. The republican movement hoped to attract international support for their cause by emphasizing the civil rights violations perpetrated by the British. Hunger strikers, allowed to die by the Thatcher government's refusal to accede to their demands, were one powerful symbol of this effort. Images of PIRA volunteers, but especially civilians and children who had died in the conflict, served a similar purpose. Such images worked to establish social cohesion through a history of shared suffering; it emphasized the toll that the conflict and the British policies meant to contain it took not only on those actively involved in combat but on the very fabric of Northern Irish society.

\section{International Revolutionary and Civil Rights Movements}

The republican mural tradition also made more explicit pleas for support from international audiences, using imagery that connected the republican movement in Ireland with a 
diverse variety of other nationalist, socialist, or civil rights movements around the world. The PIRA and Sinn Féin are nominally democratic socialist, a position which owes its roots to the working class background of the nationalist community and the efforts to promote civil equality for oppressed lower class Catholics in Northern Ireland. Indeed, one of the theoretical explanations for the conflict in Northern Ireland has been to view the struggle in Marxist terms. Republican muralists took pains to connect the movement with other socialist movements. Che Guevara was a prominent subject of republican murals, and several murals claimed solidarity with the Cuban revolution. Other murals portrayed Vladimir Lenin in an effort to connect the republican movement with Marxists thought elsewhere in the world.

Republican murals also evoked a variety of civil rights and nationalist movement that were considered the republicans' most natural allies. The African National Congress, the African-American Civil Rights Movement, the plight of Native Americans in the United States, and women's liberation movements around the world all appeared in several different murals (Rolston, 2009). One group that was prominently featured on republican wall murals was the Palestine Liberation Organization (PLO), with which the PIRA had significant connections. PIRA and PLO members trained together in Libya, and the PIRA used these connections to acquire guns and munitions for their struggle. One mural portrayed an IRA and a PLO soldier raising a rocket launcher together in a gesture of victory with the slogan "PLO IRA One Struggle" (Rolston, 1992, p. 50). Another mural depicted female militants from the PLO, the Cumann na mBan (women's division of the IRA) and the South West Africa People's Organization, all enclosed within a women's symbol (Rolston, 1992, p. 49). Other revolutionaries such as Emiliano Zapata and Nelson Mandela also appeared, as did several Civil Rights icons such as Martin Luther King Jr., Malcolm X (Rolston, 2009). Another nationalist 
movement that appeared repeatedly was the Basque separatist movement led by the ETA. Scholars have commented on the similarities between the situations in Northern Ireland and the Basque Country, (Bew, Frampton, \& Gurruchaga, 2009) and the connection was not lost on republican muralists. Foreign support was crucial to the republican cause; the connections represented in the murals echoed real life material and ideological relationships that helped sustain the PIRA and the republican movement.

Murals that focused on other civil rights and revolutionary movements from around the globe sought to link the Irish republican tradition with a greater global tradition of struggle and resistance. Republican organizations attempted to establish a community of such movements, depicting Irish republicanism as only one facet of a multidimensional conflict. Moreover, murals expressing continuity with violent revolutionary movements around the world signaled a change in republican ideology. No longer content to remain the suffering victims and martyrs portrayed in other murals, republican organizations asserted their right to use violence as a means of resistance against the colonial forces of Britain. As Frantz Fanon argued in the context of the Algerian struggle for independence, violence is often the only way of achieving freedom and independence for subjugated peoples (2004), and republican muralists visibly demonstrated their organizations' readiness to use violent tactics, against military, paramilitary, and civilian targets alike, to achieve their goals.

Other murals, connecting Irish nationalism with such well respected movements as the African American Civil Rights Movement or the Anti-Apartheid movement in South Africa, allowed republican organizations to claim a measure of legitimacy. As Barthes has explained, myths work to purify and provide a natural justification for ideological claims. Calling on the bona fides of other similar organizations around the globe allowed republican organizations to 
present themselves in a similar vein as heirs to the struggle for freedom, framing republicans as freedom fighters rather than terrorists. Such efforts sought to make natural and pure what was a movement with extraordinarily controversial tactics, making the movement's goals appear clear and legitimate and constructing an alternate historical narrative that portrayed violent conflict as a necessary element of the struggle for freedom, rather than a terrorist action designed to disrupt a legitimate governmental system.

\section{Flags, Crests, and Slogans}

Flags, shields, and other symbols of national identity that were present in the loyalist tradition also made their appearance on republican murals. The Irish Tricolour, national flag of the Republic of Ireland, was most visible in this regard, although the Starry Plow Flag of the Irish Citizens' Army, a group that took part in the 1916 Easter Rising, and the orange sunburst of the IRA's youth section, na Fianna Éireann, were also popular symbols (CAIN, a). These symbols created a sense of continuity between the current nationalist movement and its historical predecessors through a use of shared symbols. The shields of the four historical provinces of Ireland: Leinster, Munster, Connaght, and Ulster, were often represented together in a single mural as a way to affirm that the four provinces, including the six counties in Ulster that form Northern Ireland, should be united in a single state. This representation of the four provinces of Ireland reunited as one supported the nationalist movement's efforts to separate Northern Ireland from the United Kingdom. The phoenix, long associated with the republican movement due to its mythical ability to recreate itself from its own ashes upon death, was also a popular symbol. Irish nationalism and anti-imperialist elements of one form or another have been present in Ireland since the Norman and British invasions in the twelfth century, often struggling against significant odds and overwhelming opponents. The nationalist movement's adoption of the phoenix as a 
symbol signified the movement's undying commitment to the cause, continually resurrecting itself to fight for freedom and liberty.

Granted the similarities between the loyalist and republican depiction of nationalist flags and emblems, there were also important differences. While loyalist flags were frequently portrayed standing alone, often with only the emblems of loyalist paramilitary groups, republican flags and emblems appeared in election murals, next to portraits of famous leaders such as James Connolly, and amongst armed PIRA volunteers. This different use of flags and emblems reveals the different goals of the two movements. The relatively limited scope of imagery in loyalist murals put an emphasis on the flags and crests of the United Kingdom and loyalist groups alone because the loyalist community sought to support the institutional structure already in place in Northern Ireland. The nationalist community had less in the way of formal institutional organization, so the main emphasis of republican imagery was on cultural identity and therefore emphasized cultural symbols. Within the republican mural tradition the three stripes of the Irish Tricolour were ubiquitous, and appeared in a significant proportion of republican murals, laying claim to a shared heritage and a desired unity with the Republic of Ireland. These representations were particularly significant given the pressure that British authorities had put on the nationalist community through the Flags and Emblems (Display) Act among others. Nationalist symbols, and the depiction of the Irish Tricolour in particular, were banned and their display carried significant legal penalties. The defiant depiction of such politically charged symbols, painted large-scale in vibrant colors upon the very walls in republican territory, was a poignant expression of resistance to the political and cultural hegemony of the British and unionist authorities. 
Depictions of flags, shields, and crests served a similar purpose for republicans as they did for loyalists. Images of the Irish Tricolour sought to establish a cohesive Irish identity that subsumed Catholic populations in both Northern Ireland and the Republic of Ireland. Like loyalist efforts with the Union Flag, republican muralists sought to create a group from which paramilitary organizations, engaged in a political struggle, could draw support. Republican flags and emblems served objectively and subjectively, in Bourdieu's words, to define and express republican identity, emphasizing the movement's strength and cohesiveness for internal and external audiences alike. The emphasis on cultural symbols, used in conjunction with the Irish Tricolour and other expressions of identity, reveals efforts by republican organizations to rally the greater cultural community to their political cause, naturalizing and legitimizing the movement's rhetoric by creating a cultural mythos that linked Northern Ireland and the Republic of Ireland in a grand invented tradition.

\section{Republican Paramilitaries and the Armed Conflict}

Just as it appeared in the loyalist tradition, another potent theme prevalent in the republican mural tradition was the representation of the military struggle itself. This theme took a variety of forms, with representations of the armed conflict ranging from depictions of specific military operations to more abstract portrayals of weapons used by the PIRA. Republican depictions of the armed struggle were, like their loyalist counterparts, often intentionally menacing. Many murals portrayed watchful, heavily armed soldiers clad in imposing balaclavas and camouflage gear standing guard over republican-held territory or looming over border regions where nationalist and unionist communities met. One mural accompanied an armed PIRA soldier with the admonition "WARNING! Irish Republican Army Occupied Territory British Forces Enter at Own Risk"(Rolston, 1991, p. 86). Some murals portrayed British troops 
as well, either engaged in repressive acts such as assaulting children armed only with slingshots, being crushed by the Sisyphean struggle to impose a British solution on the "Irish question," or being towered over by an IRA member (Rolston 1991). Other murals portrayed PIRA paramilitaries actively firing their weapons at unseen British or loyalist foes. One mural provided a firsthand view of a particularly successful battle for the PIRA, painted from the perspective of a PIRA soldier looking past the republican line and across the battlefield at Narrow Water in County Down. ${ }^{8}$ Another mural, one which has become iconic of the violence in Northern Ireland, depicted a young boy wearing a gas mask and holding a petrol bomb during the Battle of the Bogside in 1969 (CAIN, c). ${ }^{9}$ This juxtaposition of the innocence of youth with the violence of the sectarian conflict in an urban community was a powerful image. Murals memorializing children killed in the conflict generally brought home the true costs of the conflict, suffered not only by hardened paramilitary soldiers but by innocents and children as well. This type of imagery, focusing on the violence and prominent role that the conflict played in Northern Irish society, served to strengthen republican organizations' position within the nationalist community. Depictions of PIRA and other paramilitary soldiers actively participating in the conflict and defending the community reinforced the connections between the organizations' struggle and the community from which they drew their support.

The republican movement prided itself on maintaining an unbroken culture of resistance despite facing overwhelming odds. The history of the Irish republican movement is one of heroes

\footnotetext{
818 members of the British army's Parachute Regiment were killed in this battle. (Rolston, 1992)

${ }^{9}$ This mural was created by The Bogside Artists, a group whose work is non-sectarian in origin and aims to achieve peace through cross-community discourse. Nevertheless, the striking imagery of this mural commemorates exposes the brutality of the violence of the conflict and the juxtaposition of child and petrol bomb provides pointed criticism of the social turmoil, created by the British and unionist inability to fairly govern Northern Ireland, that brought the violence to this level.
} 
and martyrs, and the images of the military struggle and the suffering that accompanied it served two ideological functions that helped construct a republican tradition. Like loyalist murals, republican portrayals of armed and threatening paramilitary soldiers provided both a warning to loyalist paramilitaries and the British Army that the republicans stood ready to defend themselves by any means necessary and a reassuring gesture to the nationalist community that someone was prepared to protect them and their interests, despite the British and Northern Irish governments' mistreatment of them. Images of suffering for the cause, however, also helped legitimize the republican movement. Despite having roots in nonviolent civil rights protest movements, the PIRA and other republican movements utilized guerrilla tactics in their efforts to achieve their goals. These tactics, including shootouts in urban areas, bombings, and assassination of public figures, at times displayed the same lack of respect for human life so lamented in republican murals that portrayed actions taken by the British Army and loyalist paramilitary organizations. While violence was advocated as a means of liberation by revolutionary scholars such as Fanon (2004), such tactics required significant justification to both more moderate nationalists in Northern Ireland and international audiences alike. Murals such as these did a great deal of ideological work towards this goal, not only highlighting the damage done to Northern Irish society, but portraying the conflict as a legitimate war between nations, with republican troops firmly entrenched as the "good guys" protecting children and families from the depredations of British and loyalist troops. By reframing the conflict in these terms, rather than as a police action between a legitimate state and a violent and extreme terrorist organization, republican paramilitary organizations were able to invent and naturalize a historical tradition very different from the one their loyalists counterparts were attempting to present. 
In all, the five main themes of the republican mural tradition reveal the ideological goals of the republican movement and the significant efforts taken by republican paramilitary organizations to mobilize support for them. Like loyalist organizations, republicans sought to create and express a powerful collective narrative and historical tradition. Rather than using these efforts to support the status quo in the manner Hobsbawm identified, however, the republican tradition used them to overturn the political and cultural relations of authority that had previously been dominated by the Protestant community. Republican muralists attempted to utilize the visual medium of murals to construct a national myth, in Barthes' terms, that presented and naturalized a specific version of Northern Irish history, albeit one very different from that propagated by the loyalist community. The republican tradition linked Irish nationalists in Northern Ireland to the Republic of Ireland and to like-minded organizations around the globe to procure international attention and support. At the same time, it emphasized martyrdom and human suffering in order to construct a unified cultural community amongst the nationalist population. These efforts sought to frame the republican movement as a struggle for freedom and civil rights, and cast the PIRA and other republican organizations as freedom fighters, not terrorists, struggling to liberate their people from the oppressive grasp of illegitimate and unfair political and cultural dominance.

\section{Conclusion}

The loyalist and republican mural traditions, though differing in several important aspects, both helped create and express the self-identity of the two sides of the conflict; they created groups that emphasized the legitimacy of their movements and the righteousness of their causes. Murals did this by creating and disseminating cultural myths that served as the foundations of invented traditions. These myths strove to depoliticize the ideological messages 
that organizations on both sides of the conflict conveyed through propaganda efforts such as murals, emptying them of the invented nature of their constructed histories and portraying them instead as natural, pure, and right in the process Barthes describes. Loyalist propaganda deliberately emphasized the powerful cultural hegemony that the unionist movement enjoyed for much of Northern Ireland's history and portrayed this as the natural and proper order of Northern Irish society. Republican murals provided a potent answer to the unionist dominance of Northern Ireland, expressing a culture of resistance that drew support from the local community, claiming continuity with earlier incarnations of Irish nationalism, and asserting solidarity with nationalist, socialist, and civil rights movements around the globe. Each movement sought to invent and portray a one-sided version of Northern Irish history that legitimized its own ideological position and political goals and presented them as the only reasonable way to view the ongoing struggle in Northern Ireland.

The grassroots character of both mural traditions is key to understanding the political culture in Northern Ireland and the psyche of the two competing sides. Political propaganda (in this case highly visible and at times provocative propaganda) was created by political and paramilitary organizations rather than by the state government. In the republican movement this was to be expected, as the PIRA and its supporters were a revolutionary nationalist movement specifically designed to topple the government, force British withdrawal from the region, and effect a reunification of Northern Ireland and the Republic of Ireland. Loyalist organizations, however, did not necessarily need to resort to the same type of community oriented political propaganda that the republican movement used so effectively. Other than the murals created for use in the Twelfth of July celebrations, the early loyalist mural tradition was very limited in scope and in thematic content. It was only with the rise of the civil rights movement and the 
PIRA campaign in the late 1960s and after that loyalist murals proliferated and became popular outside of the traditional Twelfth celebrations.

This sudden swelling of loyalist mural production suggests two important conclusions regarding the role of political murals in the contested space of Northern Ireland. First, the creation of republican and loyalist murals alike served as a deliberate effort to construct, define, and maintain the movements' self-identities. Republican murals functioned internally to exhort the nationalist population to support the revolutionary activities of the PIRA, Sinn Féin, and other revolutionary organizations while also functioning externally in an effort to assert the culture of resistance that had been created within the successive generations of the Irish nationalist movement. The PIRA's goal was to make Northern Ireland an untenable situation for British troops and the British government. Large and vibrant political murals emphasized British and loyalist forces' failure to quell the nationalist rebellion. The loyalist murals, in contrast, which changed from a celebratory tradition confined to one fortnight during the year to a prolific and directly focused propaganda effort, reflected the loyalist response to the post-hunger strike surge of republican murals and their popularity ever since. This proliferation of murals and the expansion of both mural traditions throughout the 1980s and 90s reflected and intensified the conflict between the unionist and nationalist communities that they represented, a symbolic war on the walls every bit as fierce as the physical conflict waged in the streets around them.

In this regard, the political situation in Northern Ireland illustrates Bourdieu's caution against accepting groups as a unitary social actors with clearly defined goals and rational courses of action. As Brubaker argues, this tendency to take groups as a given, accepting rhetorical and ideological assertions of unity as sociological reality, has been particularly powerful in the study of ethnic and religious conflicts, the Troubles in Northern Ireland among them. Analysis of the 
ways that paramilitary and political organizations in Northern Ireland struggled to mobilize support for their political goals, reveals that these organizations were the true motivators behind the actions and movements that are often attributed uncritically to the larger Unionist and Nationalist groups in Northern Ireland. In this case, such organizations relied upon visual imagery as a means of connecting cultural support to political organizations and goals, constructing and maintaining narratives that crafted specific group identities for the larger communities from which they sought support. Murals functioning objectively and subjectively, were intended to address both internal and external audiences, as they sought to construct new identities in which political organizations and cultural communities were inextricably linked.

The second important conclusion to be drawn from the community-level creation of murals in both unionist and nationalist areas concerns the character of Northern Ireland as a distinct political region. The segregation of Northern Ireland into discrete sectarian communities and the sentiments of independence that required communities to take the production of political propaganda into their own hands reflect the instability of Northern Ireland as a political unit and the deep-seated psychological insecurity of both sides engaged in the conflict. The nationalist community, led by republican organizations such as the PIRA and Sinn Féin, felt disenfranchised by the original government of Northern Ireland and drew in upon itself in a gesture of solidarity, expressing disaffection through violent revolution and political propaganda. The loyalist reaction to the unrest in the late 1960s, however, is even more telling. Before the nationalist movement revolted against the political status quo through the civil rights movement and the guerrilla campaigns of the PIRA, the unionist community was content to maintain control through the political power wielded by governmental officials. With the rise of civil unrest and the imposition of British troops, the loyalist community lost its confidence in the power of the 
government; loyalist paramilitary organizations and grassroots political propaganda proliferated in direct response. The loyalist recourse to grassroots propaganda efforts and violent paramilitary action was a direct manifestation of loyalists' belief that the British and Northern Irish governments were no longer capable of defending the unionist community and its interests. This lack of faith in the government and the political instability that followed was one of the defining characteristics of the Troubles in Northern Ireland, and was the underlying cause of much of the sectarian paramilitary violence that proved so devastating to Northern Irish society.

The creation of political wall murals reveals more than just the political instability within Northern Irish society. This continued need to construct and reinforce cultural identity reveals the ambiguous relationship and tension between organizations on both sides of the conflict and the greater cultural communities from which they drew their support. Far from the monolithic and unitary traditions that mural creators attempted to portray, political and paramilitary organizations often struggled to obtain and maintain support for their causes. Violence, terrorist campaigns, and questionable ethical activity by organizations on both sides of the conflict created a continued crisis of legitimacy in which organizations needed to justify their continued presence and political actions. The vibrant and visible wall murals that proliferated throughout Belfast and Londonderry were one means by which organizations could powerfully express their political message and argue for the necessity of continued support for their cause. Intentionally used to construct and mobilize cultural groups to support political causes, wall murals played a critical role in the strategies of organizations that were locked in a vicious physical and ideological struggle for power. 


\section{References}

Barthes, R. (1972). Mythologies (A. Lavers, Trans.). New York: Hill and Wang.

Bew, J., Frampton, M., \& Gurruchaga, Í. (2009). Talking to Terrorists : Making Peace in Northern Ireland and the Basque Country. New York: Columbia University Press.

Bourdieu, P. (1989). Social Space and Symbolic Power. Sociological Theory, 7(1), 14-25.

Brubaker, R. (2004). Ethnicity Without Groups. Cambridge, Mass.: Harvard University Press.

CAIN (a). Flags Used in Northern Ireland Retrieved 04/16, 2012, from http://cain.ulst.ac.uk/images/symbols/flags.htm

CAIN (b). Internment - Summary of Main Events Retrieved 04/16, 2012, from http://cain.ulst.ac.uk/events/intern/sum.htm

CAIN (c). The Petrol Bomber - Battle of the Bogside Retrieved 04/16, 2012, from http://cain.ulst.ac.uk/bogsideartists/mural1/

Crowley, T. Murals of Northern Ireland Retrieved November 1, 2011, from http://ccdl.libraries.claremont.edu/collection.php?alias=/mni

Darby, J. (1976). Conflict in Northern Ireland: The Development of a Polarised Community. Dublin: Gill and Macmillan.

Fanon, F. (2004). The Wretched of the Earth (R. Philcox, Trans.). New York: Grove Press.

FitzGerald, G. (2006). The 1974-5 Threat of a British Withdrawal from Northern Ireland. Irish Studies in International Affairs Irish Studies in International Affairs, 17(1), 141-150.

Gardiner, G. (1975). Report of a Committee to Consider, in the Context of Civil Liberties and Human Rights, Measures to Deal with Terrorism in Northern Ireland. London: H.M.S,O.

Grant, P. (1999). Breaking Enmities: Religion, Literature, and Culture in Northern Ireland, 1967-97. New York: MacMillan; St. Martin's Press.

Hobsbawm, E. J., \& Ranger, T. O. (1983). The Invention of Tradition. Cambridge and New York: Cambridge University Press.

Jarman, N. (1992). Troubled Images. Critique of Anthropology, 12(2).

Jarman, N. (1997). Material Conflicts : Parades and Visual Displays in Northern Ireland. Berg, Oxford [England]; New York. 
Jarman, N. (1998). Painting Landscapes: The place of Murals in the Symbolic Construction of Urban Space. In A. D. Buckley (Ed.), Symbols in Northern Ireland. Belfast: Institute of Irish Studies, Queen's University of Belfast.

Marschall, Sabine. (2007). "A Postcolonial Reading of Mural Art in South Africa." Critical Arts : South-North Cultural and Media Studies 14(2), 96-121.

Marx, K., \& Engels, F. (1972). Ireland and the Irish Question: A Collection of Writings by Karl Marx and Frederick Engels. New York: International Publishers.

McCormick, J. (03/14/2011). Introduction to the Directory of Murals Retrieved November 1, 2011, from http://cain.ulst.ac.uk/mccormick/index.html

McGarry, J. \& O'Leary, B. (2000). Explaining Northern Ireland: Broken Images. Oxford: Blackwell.

McKittrick, D. (1999). Lost Lives: The Stories of the Men, Women, and Children Who Died as a Result of the Northern Ireland Troubles. Edinburgh: Mainstream.

Miller, D. (1994). Don't Mention the War: Northern Ireland, Propaganda, and the Media. London; Boulder: Pluto Press.

Moloney, E. (1991). Closing Down the Airwaves: The Story of the Broadcasting Ban. In B. Rolston (Ed.), The Media and Northern Ireland Houndsmills/Basingstoke: Macmillan.

Murray, R. (1998). State Violence in Northern Ireland, 1969-1997. Cork: Mercier.

O'Brien, B. (1999). The Long War: The IRA and Sinn Fein. Syracuse, N.Y.: Syracuse University Press.

Reed, T. V. (2005). The Art of Protest : Culture and Activism from the Civil Rights Movement to the Streets of Seattle. Minneapolis: University of Minnesota Press.

Rolston, B. (1976). Containment and Its Failure: The British State and the Control of Conflict in Northern Ireland. In A. George (Ed.), Western State Terrorism. Cambridge: Polity Press.

Rolston, B. (1991). Politics and Painting: Murals and Conflict in Northern Ireland. Cranbury: Associated University Presses.

Rolston, B. (1992). Drawing Support: Murals in the North of Ireland. Belfast: Beyond the Pale

Rolston, B. (1995). Drawing Support 2: Murals of War and Peace. Belfast: Beyond the Pale.

Rolston, B. (1998). From King Billy to Cu Chulainn: Loyalist and Republican murals, Past, Present, and Future. [Article]. Eire-Ireland, 33(1-2), 6-28. 
Rolston, B. (2003). Drawing Support 3: Murals and Transition in the North of Ireland. Belfast: Beyond the Pale.

Rolston, B. (2009). "The Brothers on the Walls" International Solidarity and Irish Political Murals. Journal of Black Studies, 39(3), 446-470.

Rolston, B. (2010). 'Trying to Reach the Future Through the Past': Murals and Memory in Northern Ireland. Crime Media Culture, 6(3), 285-307.

Sluka, J. (1992). The Politics of Painting: Political Murals in Northern Ireland. In: Carolyn Nordstrom \& JoAnn Martin (Eds.), The Paths to Domination, Resistance, and Terror. [Berkeley]: University of California Press.

Sluka, J. A. (1995). Domination, Resistance and Political-Culture in Northern Ireland's CatholicNationalist Ghettos. [Article]. Critique of Anthropology, 15(1), 71-102.

Sluka, J. A. (1996). The Writing's on the Wall - Peace Process Images, Symbols and Murals in Northern Ireland. [Article]. Critique of Anthropology, 16(4), 381-394.

Thornton, R. (2007). Getting it Wrong: The Crucial Mistakes Made in the Early Stages of the British Army's Deployment to Northern Ireland (August 1969 to March 1972). Journal of Strategic Studies, 30(1), 73-107.

van Henten, J. W., \& Houtepen, A. W. J. (Eds.). (2001). Religious Identity and the Invention of Tradition. Assen, The Netherlands: Royal Van Gorcum.

Vannais, J. (2001). Postcards from the Edge: Reading Political Murals in the North of Ireland. Irish Political Studies, 16, 133-160.

Zimmerman, G. (2002). Songs of Irish Rebellion: Political Street Ballads and Rebel Songs, 1780-1900. Dublin: Four Court Press. 